\title{
Congressional Views on NATO Enlargement: Limited Domestic Interest with Few Votes to Gain
}

\author{
Ryan C. Hendrickson
}

\section{Introduction}

AtNATO's 2014 Wales Summit, the alliance, across a number of issue-areas, reaffirmed its interest in expanding its outreach activities and partnerships. Whether it is the possibility of new partnerships on missile defense, the improvement of NATO's Naval and cyber-defense capabilities to work more effectively with other international organizations, partners, or nonpartner states, or in general the backing for new partnerships, the Wales Summit Declaration expressed broad sentiment for an increasingly global military organization (Edström, Haaland and Petersson 2011). On future enlargement plans, most significantly the document states:

NATO's door will remain open to all European democracies which share the values of our Alliance, which are willing and able to assume the responsibilities and obligations of membership, which are in a position to further the principles of the Treaty, and whose inclusion will contribute to the security of the North Atlantic area. We reaffirm our strong commitment to the Euro-Atlantic integration of the partners that aspire to join the Alliance, judging each on its own merits (Wales Summit Declaration 2014). 
The Summit declaration was followed by expressing their ongoing support for the NATO membership aspirations of Georgia, Montenegro, Bosnia and Herzegovina, as well as by calling for a resolution to the ongoing debate between Greece and Macedonia over its name so that Macedonia can eventually join the alliance. In addition, President Obama continues to support the idea of enlargement, as do senior American officials (Obama 2014; Nuland 2014). Thus, though reservations remain for any immediate membership expansion, by a number of measures it is clear that NATO intends to increasingly expand its partnerships, and will continue to assert an interest in having new members.

When evaluating how NATO has expanded in previous enlargement rounds, the United States has often played the determinative role in shaping when and how many new members will be invited to join the alliance. At NATO's Madrid Summit in 1997, it was U.S. Secretary of State Madeleine Albright who announced that only three aspiring NATO allies would be invited to join NATO. After difficult and somewhat contentious diplomatic negotiations among the allies, she got what she initially promulgated (Asmus 2002). Similarly, when President George W. Bush first traveled to Europe in June 2001 and shocked the allies by announcing his desire to "erase the Yalta line" and advance a broad agenda for membership expansion, he got what he sought at NATO's Prague Summit in 2002, when seven new allies were invited to join (Hendrickson and Spohr-Readman 2004).

Given the United States' influential role in previous rounds, coupled with NATO's ongoing interest in NATO expansion, this paper turns to the potential role that the United States Congress may play in shaping this political process. As is evident below, some members of Congress have demonstrated strong and meaningful interest in NATO enlargement and in NATO policies more generally (Petersson forthcoming). At times, especially in the lead up to NATO's Madrid Summit in 1997, members of Congress played an important role in shaping American foreign policy and the larger strategic dialogue on NATO expansion. The evidence presented here, however, maintains that while some members of Congress have recently expressed interest in NATO expansion, few constituency political incentives exist for members to actively support enlargement. Thus, due to rather minimal issue saliency for most members of Congress, most 
legislators remain disengaged from the issue, which will likely dampen efforts to expand NATO, and keep NATO membership at its current size. Moreover, since the crisis in the Ukraine, the enlargement issue has taken on a new partisan identity that may also limit the extent to which greater support for membership expansion develops in a substantive and more comprehensive way.

\section{Literature Review}

In discussing Congress's foreign policy activities, and in particular with regard to congressional attention to NATO, at least four bodies of scholarship have been recognized as research that provides insight on what may inspire or generate legislative activism (Hendrickson 2015). ' One body of literature focuses on members of Congress interest in keeping their elected seat. Among the most notable scholars who made this claim, David Mayhew maintained that everything members of Congress do is generally motivated by their interest in getting reelected (Mayhew 1974). Mayhew's views have found some support among foreign policy analysts, who argue that members of Congress will work to keep their constituencies pleased. Such activity may mean that members of Congress will extend their support to active and vocal interest groups in their districts (Rubenzer 2011 ; Cutrone and Fordham 2010; Souva and Rohde 2007). Indeed, when members of Congress chose to support NATO's first round of expansion in 1998, they were targeted and aggressively lobbied by the Polish American Congress, the Hungarian-American Coalition, and other ethnic-American interest groups to support their desire to join NATO (Sloan 2003: 147).

Another body of scholars who address congressional foreign policy activism is those who identify partisanship as a key variable in explaining such behavior. A number of studies have found that members of Congress are indeed quite partisan on foreign policy issues (Carter and Scott 2009; Johnson 2006; Auerswald and Matlzman 2003). Over the course of Congress's historical relationship with NATO, however, few scholars point

1 See especially chapter 5 for a similar analytical approach. 
to the presence of strong partisan legislative activism. Certainly, many more republican members of Congress, rather than democrats, raised concern with President Clinton's deployment of U.S. peacekeepers to NATO's 1995 peacekeeping mission in Bosnia (Hendrickson 2002). Some republicans similarly opposed President Obama's military strikes and coordination with the alliance during the NATO military operation in Libya in 2011 , though opposition was not exclusively partisan either (Hendrickson 2013). Yet in terms of Congress's views on NATO's strategic decisions in the past, partisan activities are difficult to identify.

A third body of scholarship that may help explain Congress's activities on NATO is a general deference to presidential decisions related to the alliance. Much scholarship on Congress, especially research that examines congressional views on American military policies and military actions abroad, argues that Congress often simply follows the president's lead (Hendrickson 2015; Fisher 2013; Griffin 2013; Moss 2008; Ely 1990; Glennon 1990; Weisman 1995; for an exception see Howell and Pevehouse 2007). This literature squares with findings that Congress was largely disengaged from NATO's actions during much of the Bush presidency, as few members of Congress provided oversight of NATO's activities in Afghanistan, or NATO's operations in Darfur and Iraq (Hendrickson 2007).

Congress's oversight of the 2002 Prague Summit expansion round could also be categorized as deference to President George W. Bush as all senators, in unanimous fashion, went along with Bush's expansion request (Nowlton 2003). In evaluating the possible new applicants to NATO, most senators focused on whether the applicant states had backed the United States and its war in Iraq, which appeared as the key assessment measure when senators rose to express their support for the expansion plan. Unlike the Senate's discussions of the Madrid enlargement round, there was very little substantive debate over the strategic merits of adding the "Prague invitees" to the alliance (Hendrickson and Spohr-Readman 2003). In a similar degree of deference, the Senate approved of Albania's and Croatia's membership invitations in 2008 through a unanimous consent procedure, and thus entailed no debate or floor discussion of these applicant states (Congressional Record September 25, 2008).

However, there have been cases in NATO's history when individual 
members of Congress have expressed strong interest in matters related to NATO, which squares with a fourth body of research that argues for simply the presence of some members' personal policy interests as motivation for their activity on a particular foreign policy issue (Carter and Scott 2009; McCormick and Mitchell 2007; Burden 2007; Carter 2004; Hammond 1998). This body of scholarship could also be captured by noting that certain members of Congress may simply be motivated by their own unique personal beliefs on a certain set of issues that helps generate activism. For example, Senator Richard Lugar (R-In.) has been credited with leading the cause in Congress for NATO to reform itself upon the Soviet Union's collapse, and as an early and strong advocate for NATO's initial post Cold War enlargement (Sloan 2003: 147; Goldgeier 1999: 35). Indeed, in the Senate's lead-up vote for the Madrid membership enlargement proposal in 1998, many members followed Lugar's initial lead and engaged deeply in a deliberative and nonpartisan evaluation of the applicant states in question (Sloan 2003: 148-153; Goldgeier 1999: 145-151).

Senator Sam Nunn (D-Ga.) was another important independent legislative voice in often pushing NATO's European allies to accept a greater share of defense spending burdens. Similarly, Senator Mike Mansfield (D-Mt.), in the 1960s, also often placed pressures on the allies by threatening the removal of American troops from European deployments (Kaplan 1984: 27). Thus, across NATO's lifespan, individual members of Congress have on occasion risen to express their concerns over NATO's directions, and at times, have injected important and meaningful suggestions and pressures on their sitting presidents or the allies. Individual members of Congress can help drive and shape a foreign policy issue.

In sum, four broad expectations of behavior can be extrapolated from this previous scholarship. First, if there is congressional activity, one may expect that such behavior may be inspired by constituency pressures and the desire to get reelected, all of which would suggest that this issue has higher electoral saliency. Second, if there is legislative activity on NATO enlargement, partisanship may be a factor that provides insight. Similarly, Congress may also engage in partisan challenges to the president. Third, if there is very little congressional activism, one may anticipate some degree of deference or silence on this issue, which often seems the case in national security affairs. Fourth, and finally, there may also be 
individual members of Congress who have developed a strong interest in foreign policy issues, and thus perhaps have a long-standing interest in NATO enlargement, which would help advance or perhaps limit NATO enlargement, which was especially evident prior to the Madrid Summit enlargement.

At the same time, one must recognize that these categories of activities could easily overlap and are not mutually exclusive; a very partisan member of Congress may also have strong incentives to act in such a manner due to constituency pressures, especially if one is from a politically homogenous district. A personal policy interest could also very legitimately appear as a strongly partisan view of an issue, which makes it very difficult to determine why a member of Congress is taking a stand on an issue. Thus, determining the motives for these actions is very difficult, if not impossible, and thus some congressional foreign policy activity may overlap among these categories in the analysis that follows (McCormick and Mitchell 2007).

The rest of the paper examines congressional views on a potential next round of NATO enlargement, focusing mostly on activities in 2012, 2013 and 2014. Searches were conducted of the Congressional Record, as well as Lexis-Nexis to identify members of Congress who advanced proposals regarding NATO enlargement. For this project, no committee hearings were examined, which potentially presents a limitation to this research, though perhaps not a significant limitation given how few congressional committees carried out oversight of NATO issues during the Bush presidency (Hendrickson 2007).

\section{Constituency pressures}

Unlike the political processes that occurred surrounding the Senate's debates over NATO Madrid Summit enlargement, among the aspiring and potential new members, there are few ethnic-American interest groups that yield significant influence in American domestic politics to 
lobby on behalf of their home states. Among the possible candidates who were mentioned in the Wales Summit declaration, including Montenegro, Bosnia and Herzegovina, and Georgia, these states have weak domestic lobbies in the United States and thus few votes are to be gained by actively advancing enlargement on behalf of these states. This is a markedly different environment when compared to the number of Polish-Americans in the United States, who were well-organized and active across the United States during discussions of the Madrid expansion round (Goldgeier 1999: 52, 99).

One member of Congress, Carolyn Maloney (D-N.Y.), however, has views that appear to square closely with her district's constituency related to NATO enlargement. Maloney, who serves as the founder and co-chair of the congressional caucus on Hellenic Issues notes: "I am privileged to represent a large population of Greeks in my New York City district, the city that is home to the largest Hellenic population outside of Greece and Cyprus" (Greek Reporter 2014). Thus, it is perhaps not surprising that she has sided with Greece in the ongoing debate over the possible admission of the Former Yugoslav Republic of Macedonia into NATO, which was conditionally invited to join the alliance in 2008 at NATO's Bucharest Summit upon some revision of its name, "Macedonia," which the Greeks oppose (Congressional Record 2014).

In contrast, Congressman Mike Turner (R-Oh.), who has a long and sustained interest in NATO and NATO enlargement issues, was commended by the United Macedonia Diaspora (UMD) for his support of Macedonia's potential membership in NATO. A UMD representative noted:

Ohio is home to some of the oldest Macedonian communities in the United States, where immigrants started arriving in the early 1900s to help build this great country...It's encouraging to see Congressman Turner, a member of the Congressional Caucus on Macedonia, getting engaged in this way on behalf of his constituents (United Macedonia Diaspora 2012).

Apart from these examples, it is difficult to identify the presence of any meaningful political pressure on members of Congress to support membership expansion due to strong constituency pressures. Certainly, there may be small pockets of strong ethnic-American interest group 
pressures placed upon some members of Congress to act on this issue, which another more comprehensive research approach may discover, but in this case, no members appear to reflect the "constituency pressure" position better than Congresswoman Maloney or Congressman Turner--though Turner's actions can also fall very legitimately into the following category of "personal policy interests." In sum, due to the limited political and electoral incentives for engagement in this issue, NATO enlargement has rather low issue saliency, and thus few members of Congress who appear interested in NATO's future expansion.

\section{Personal policy interests}

To identify members of Congress who have a personal policy interest or a strong personal belief on NATO enlargement in the time period under analysis, one can assess if this person has expressed a sustained interest in the issue, and also may have exhibited some degree of bipartisan cooperation to help advance the cause. Two members of Congress who appear to fit this standard are Congressmen Michael Turner (R-Oh.), noted above, and Eliot Engel (D-N.Y.). Turner has served as a delegate to the NATO Parliamentary Assembly since 2011, and currently serves as its President. Engel is the ranking minority member on the House Foreign Affairs Committee, and has a long-standing interest in American foreign policy issues.

Prior to the crisis in Crimea, Turner and Engel introduced a bipartisan proposal, signed by additional 38 members of Congress, which advanced a number of policies related to NATO enlargement. The proposal included the call for Montenegro to be invited to join the alliance; a resolution to the "Macedonia" name dispute in order to result in their membership in NATO; a compliment to Bosnia and Herzegovina for its activities in the Membership Action Program (MAP); for Georgia to be invited to join the MAP; and for Kosovo to become an active member of NATO's Partnership for Peace. This proposal came in a letter sent to Secretary of State John Kerry, prior to the NATO's Wales Summit, and included signatures from 21 Republicans and 19 Democrats (Engel 2014). Congressman Turner, on 
many occasions, has since reiterated these positions, both in the United States and abroad (Congressional Record 2014; Civil.ge 2012; German Marshall Fund 2014). Engel, too, has previously been engaged on NATO enlargement issues (Engel 2009). Thus, given the bipartisan nature of the proposal and these members' sustained interest on this issue, a case can be made for their personal policy interests here.

In addition, Congressmen John Shimkus (R-IL) and Adam Schiff (D-CA), co-chairs of Congress's Baltic Caucus, have also advanced various proposals for NATO expansion (ShimkUs 2014; Shelbyville Daily News 2014; Embassy of the United States, Lithuania 2014). Shimkus's views are especially interesting given that he has noted that there are few political incentives for him to serve on this caucus, given the limited number of people in his district of Baltic descent. In fact, Shimkus noted that he was recruited by caucus supporters to join the organization, and thus implicitly noted that membership and support for the caucus was not something he had considered prior to joining (Shimkus 2014a). Like Congressman Turner, Shimkus also served as an American delegate to the NATO parliamentary Assembly, but has since resigned from this position. Nonetheless, while neither Shimkus nor Schiff appear to have as extensive records on this issue when compared to Turner and Engel, both have advanced policy positions that do not easily seem to correlate with district preferences or the presence of diaspora populations living in their districts, which suggests a personal policy interest in the issue.

One additional member of Congress who has demonstrated a sustained interest in NATO enlargement is Senator John McCain (R-AZ). Among members of the United States Senate, no other senator has generated as much media coverage on NATO enlargement. McCain's views have been clear since prior to NATO's Chicago Summit in 2012 and in the lead up to the Wales Summit in 2014. McCain has consistently advocated for NATO's membership expansion. In 2012, prior to Chicago, McCain noted:

We hear it said that this will not be an expansion summit. That is regrettable. We must make it clear to all of these countries, and any other country in Europe that wants to be a part of NATO and can meet the criteria, that the path to membership is open to them (quoted in Brannen 2012). 
McCain, along with Senator Lindsey Graham (R-S.C.) have also lobbied President Obama directly to expedite Georgia's call for membership in NATO (Bennett 2013). McCain has also expressed backing for Montenegro's request for membership as well (News Europe 2014). Thus, McCain is not new to this issue and has demonstrated a sustained interest in the cause. His positions, in the wake of the crisis in Crimea and Eastern Ukraine, however, appear to have taken on a more partisan quality, or at minimum, are more anti-Obama in their presentation.

\section{Partisanship}

As noted above, it is very difficult to distinguish between a member's personal policy interest in an issue, and a member's ideological preferences that may appear to be quite partisan in nature. Thus, analytically this is very difficult to distinguish and categorize. There are at least three recent actions, however, in the wake of Russia's military interventions in Ukraine, that certainly have a more partisan complexion than the bipartisan proposals advanced earlier in 2014 from Congressmen Engel and Turner.

First, John McCain's criticism of President Obama's response to Russia's invasion of Ukraine has been quite forceful. McCain has noted that "Obama Has Made America Look Weak" and that in this new security environment, it has been a mistake not to continue with NATO enlargement (McCain 2014).

McCain, along with GOP Senators John Barrasso (R-Wy) John Hoeven (R-N.D.) and Ron Johnson (R-Wi) also published an opinion editorial in the Washington Post, in which they noted:

The west must provide far greater diplomatic, economic and military support to Ukraine, Moldova, Georgia and other European countries that aspire to be part of our transatlantic community. We must show all of these countries that, as long as they meet the rightfully high standards for membership, the doors to NATO and the European Union remain open (McCain, Barrasso and Johnson 2014). 
While these positions may indeed have policy legitimacy, the fact that no democrats joined as co-authors, and only Republican Senators penned the editorial, suggests some measure of partisanship.

Congressman Mike Turner (R-Oh) also became increasingly active on NATO enlargement issues in the wake of Russia's new militarism. On 27 March, 2014, Turner introduced the "NATO Alliance Recognition and Promotion Act" introduced by Congressman Mike Turner (R-Oh.), which simply called upon the House to appreciate the significant political gains produced through past enlargement rounds, and to continue with "enlargement activities." His proposal was co-sponsored by nine republicans and only one democrat." Turner also introduced the "Forging Peace Through Strength in Ukraine and Transatlantic Alliance Act" on 9 April, 2014, which like his previous proposals, included calls for "NATO membership for Montenegro, a NATO Membership Action Plan for Georgia, a diplomatic solution to disputes between Macedonia and Greece, and [to] seek resolution to the constitutional issues in Bosnia and Herzegovina" (House Resolution 4433, 9 April 2014). It is notable that only two co-sponsors signed with Turner: Mike Rogers (R-Al) and Howard McKeon (R-Tx). Why no democrats co-sponsored the legislation is not apparent, though it is clear that only three republicans advanced the bill.

In the Senate, apart from the media outreach efforts made by McCain and his fellow republicans, one response to the Ukraine crisis was led by Senator Bob Corker (R-Tenn.), the then ranking minority member of the Senate Foreign Relations Committee. He, along with 22 GOP senators, called for a more aggressive and active policy toward Russia, which included the proposal to grant Major Non-NATO Ally (MNNA) status to Ukraine, Moldova and Georgia. While the distinction of being a MNNA is not the same as becoming a NATO ally, this proposal is nonetheless another means of moving the United States closer to these states ( $S$. 2277, 1 May 2014). Again, a notable feature of the proposal is that only republicans signed on as co-sponsors.

In sum, some indications exist that suggest a heightened degree of partisanship present in both the House and Senate in the aftermath

2 The one democrat was Charles Rangel (D-N.Y.). See House Resolution 4346 (27 March, 2014) at https://www.govtrack. us/congress/bills/113/hr4346/text (Accessed 5 January, 2015). 
of Russia's action. The absence of bipartisanship is evident across these recent proposals, which introduces a new political dynamic into Congress's domestic consideration of NATO's future enlargement.

\section{Deference}

As is clear from the data above, a number of members of Congress have expressed interest, and in some cases, sustained attention to the issue of NATO enlargement. In this sense, congressional activity is alive and well. At the same time, the congressional activity identified is from a rather small pool, which at its peak included 40 members of the House of Representatives, or less than ten percent of the chamber. Moreover, President Obama has not chosen to actively advance an enlargement agenda, which for most members of Congress, at least thus far, appears to be politically acceptable. Widespread opposition to Obama's views does not exist, and those who are advocating for a different political direction do not appear to be gaining political traction. In this respect, most members of Congress, at least tacitly, appear to agree with President Obama, or are not engaged on the issue. Thus, as President Obama seems relatively unengaged on this issue, so too are most of the members of Congress. As noted above, this absence of interest may also be explained by the generally low issue saliency of NATO's future enlargement.

Perhaps the diplomatic complexity of the Russian-Ukraine issue has pushed the NATO enlargement question to the wayside for now, and given the more partisan complexion of how NATO enlargement is now being presented by some members of Congress, many members-especially democrats--are choosing to simply follow President Obama's lead and not inject new positions into the wider debate over how to manage this crisis. Thus, deference, especially from the House and Senate Democrats, appears to be the chosen strategy on the specific issue of NATO enlargement at this time. 


\section{Conclusion}

Congress's attention to NATO's possible membership expansion can, in part, be explained by four bodies of scholarship on congressional foreign policy activism. First, the evidence presented here suggests that the vast majority of members of Congress is either content with the current status of NATO enlargement or is simply not engaged in this issue. These findings lend support to the literature that views Congress as largely deferential to the president in foreign policy. In the last three years, both houses of Congress have generated no major legislative initiatives to help shape the debate over NATO's future enlargement. It is clear that as an institution, Congress is not pushing a new enlargement agenda.

Second, some of this deference may be shaped by the few electoral incentives and low issue saliency in place that may be necessary to generate enthusiasm for this issue, which also lends credence to those scholars, like David Mayhew (1974), who argue that members of Congress remain focused most importantly on reelection. Given the small ethnic American diaspora(s) that exists in the United States, working to advance their home-states' cause for membership in NATO, the political incentives are simply not there to inspire major and sustained efforts to encourage another round of NATO enlargement.

At the same time, there indeed are pockets of congressional activity related to NATO enlargement, which help lend support to the idea that indeed there are members of Congress who have a personal policy interest in NATO's enlargement. The 2014 proposal advanced by Congressmen Engel and Turner offers the most substantive and bipartisan example of Congress's interest in future expansion. These efforts, however, have become subsumed by a more polarized debate and presentation of NATO enlargement, as Republicans have become somewhat more active in advancing NATO enlargement proposals, while Democrats have distanced themselves from such initiatives. This heightened partisanship will likely make it more difficult to advance this issue and generate wider support for the cause in the United States Senate, especially as Senator John McCain (R-Az.), rightly or wrongly, becomes increasingly more outspoken on President Obama's diplomatic initiatives on Ukraine. Thus, 
partisanship has now arguably crept into the question of NATO expansion, which scholars have identified as another variable in congressional activism. In sum, all four bodies of previous scholarship on congressional foreign policy activism (or deference) help provide some insight on how Congress may shape the next possible round of NATO's expansion.

All of these findings suggest that NATO is unlikely to enlarge in the near future. As most members of Congress appear to be deferring to President Obama on this issue, and as Obama appears relatively unengaged, NATO is unlikely to expand its membership. Indeed, as demonstrated above, some members of Congress are engaged on this issue, but given how few political incentives exist, the status quo seems like a probable scenario in the near future. Among the candidates who seek admission, Montenegro seems the most likely, given that in the past, both democrats and republicans have expressed support for this country. In the event the President Obama and the NATO allies proposed Montenegro as a new member, as long as partisanship does not overwhelm congressional dialogue and debate of this issue, Congress would likely defer to Obama's wishes. Otherwise, it is difficult to foresee a serious policy effort from Obama or the Congress to enlarge NATO, especially given the few domestic political and electoral incentives for doing so. 


\section{BIBLIOGRAPHY}

Asmus, R. D., 2002. Opening NATO's Door. New York: Columbia University Press.

Auerswald, D. and Matlzman, F., 2003. Policymaking Through Advice and Consent: Treaty Considerations by the United States Senate. Journal of Politics 65(4): 1097-1110.

Bennett, J. T., 2013. "McCain, Graham Call for NATO Expansion, Missile Interceptors". Defensenews.com, August. Available at http:// archive.defensenews.com/article/20130808/DEFREG02/308080013/ McCain-Graham-Call-NATO-Expansion-Missile-Interceptor (accessed 10 February 2015).

Brannen, K., 2012. "McCain: Syrian, NATO Expansion Should Be on Summit Agenda". Defensenews.com, 20 March 2012. Available at http://archive.defensenews.com/article/20120320/ DEFREG02/30320001 1/McCain-Syria-NATO-Expansion-ShouldSummit-Agenda (accessed 10 December 2014).

Burden, B.C., 2007. Personal Roots of Representation. Princeton: Princeton University Press.

Carter, R. G., and Scott, J. M., 2009. Choosing to Lead: Congressional Foreign Policy Entrepreneurs. Durham, NC: Duke University Press.

Carter, R. G., Scott, J. M. and Rowling, C. M., 2004. Setting a Course: Congressional Foreign Policy Entrepreneurs in Post-World War II U.S. Foreign Policy. International Studies Perspectives 5: 278-299.

Embassy of the United States Vilnius, Lithuania, 2014. "Congressman Adam Schiff's Speech at the International Conference of Parliaments to NATO Enlargement". Embassy of the United States Vilnius, Lithuania, 28 March 2014. Available at http://vilnius.usembassy. gov/mobile//news-events/congressman-adam-schiffs-speech-atthe-international-conference-contribution-of-parliaments-to-natoenlargement.html (accessed 13 January 2015). 
( Congressional Record 2003. (8 May 2003): S5885.

Congressional Record 2008. (25 September): $\$ 9554$.

Congressional Record 2014. (11 February): E197.

Congressional Record 2012. (25 March): E1224.

Cutrone, E. A. and Fordham, B. O., 2010. Commerce and Imagination: The Sources of Concern about International Human Rights in the US Congress. International Studies Quarterly 54(3): 633-655.

Edström, H., Matlary, J. H. and Petersson, M., eds., 2011. Utility of NATOUtility for NATO? New York: Palgrave.

Engel, E., 2014. "Engel Signs Bipartisan Letter to Kerry Urging NATO Enlargement" 10 February 2014. Available at http://engel.house. gov/latest-news 1/engel-signs-bipartisan-letter-to-kerry-urgingnato-enlargement/ (accessed 10 December 2014).

Engel, E., 2009. "Eliot Engel on NATO Membership Protocol signin/RTV21". Available at https://www.youtube.com/watch?v=4_OQ2dj9BZU (accessed 10 December 2014).

Ely, J. H., 1990. War and Responsibility: Constitutional Lessons of Vietnam and Its Aftermath. Princeton: Princeton University Press.

Fisher, L., ed., 2013. Presidential War Powers. Lawrence, KS: University of Press of Kansas.

Civil.ge, 2012. "Georgia in Congressman Turner's NATO Bill". Available at http://www.civil.ge/eng/article.php?id=24595 (accessed 15 December 2014).

German Marshall Fund, 2014. "Congressman Turner Outlines Potential response to Russian Actions". German Marshall Fund's Brussels Forum, 23 March 2014. Available at http://brussels.gmfus.org/ congressman-turner-outlines-potential-response-to-russian-actions/ (accessed 15 December 2014).

Glennon, M. J., 1990. Constitutional Diplomacy. Princeton: Princeton University Press.

Goldgeier, J. M., 1999. Not Whether But When: The U.S. Decision to Enlarge NATO. Washington D.C: Brookings Institution. 
Greek Reporter, 2014. "Rep. Maloney Honors Greek Independence Day". Greek Reporter, 25 March 2014. Available at http://usa. greekreporter.com/2014/03/25/rep-maloney-honors-greekindependence-day/ (accessed 10 November 2014).

Griffin, S., 2013. Long Wars and the Constitution. Cambridge: Harvard University Press.

Hammond, S. W., 1998. Congressional Caucuses in National Policy Making. Baltimore, MD: Johns Hopkins University Press.

Hendrickson, R. C., 2015. Obama at War: Congress and the Imperial Presidency. Lexington, KY: University Press of Kentucky.

Hendrickson, R. C., 2013. Libya and American War Powers: War-Making Decisions in the United States. Global Change, Peace and Security 25(2): 175-189.

Hendrickson, R. C. and Spohr-Readman, K., 2004. "From the Baltic to Black Sea: Bush's NATO Enlargement". White House Studies, 4(3): 319-336.

Hendrickson, R. C., 2002. The Clinton Wars: Congress, the Constitution, and War Powers. Nashville, TN: Vanderbilt University Press.

Hendrickson, R. C., 2007. L'OTAN et George W. Bush: Perspectives du Congrès américan sur la transformation de l'alliance. Études internationals, 38(4): 475-99.

House Resolution 4433, 9 April 2014. Available at https://www.congress. gov/bill/113th-congress/house-bill/4433 (accessed 5 January 2015).

Howell, W. G. and Pevehouse, J. C., 2007. While Dangers Gather; Congressional Checks on Presidential War Powers. Princeton, N.J.: Princeton University Press.

Johnson, R. D., 2006. Congress and the Cold War. New York: Cambridge University Press.

Kaplan, L. S., 1984. The United States and NATO: The Formative Years. Lexington, KY: University Press of Kentucky.

Mayhew, D., 1974. The Electoral Connection. New Haven: Yale University Press.

McCain, J., 2014. "Obama Has Made America Look Weak". New 
York Times, 15 March 2014. Available at http://www.nytimes. com/2014/03/15/opinion/mccain-a-return-to-us-realism.html?_r=0 (accessed 10 December 2014).

McCain, J., Barrasso, J., Hoeven, J. and Johnson, R., "A New Strategy for the Real Russia". Washington Post, 27 April 2014: A15.

McCormick, J. M. and Mitchell, N. J., 2007. Commitments, Transnational Interests, and Congress, Who Joins the Congressional Human Rights Caucus? Political Research Quarterly, 60(4): 579-592.

Moss, K. B., 2008. Undeclared War and the Future of U.S. Foreign Policy. Baltimore: Johns Hopkins University Press.

News Europe, 2014. "US to Support Montenegro's membership in NATO". 13 April 2014) Available at http://www.neurope.eu/article/ussupport-montenegro\%E2\%80\%99s-membership-nato (accessed 10 March 2015).

Nowlton, B., 2003. "Senate Votes Unanimously to Approve Expansion of NATO". Available at http://www.nytimes.com/2003/05/08/international/ worldspecial/08CND-NATO.html (accessed 10 March 2015).

Nuland, V., 2014. "State's Nuland Press Availability with PM Gruevski in Macedonia". 14 July 2014. Available at http://iipdigital. usembassy.gov/st/english/texttrans/2014/07/20140715304004. html\#axzz3U16HZ6Wn (accessed 10 October 2014).

Petersson, M., forthcoming. The US NATO Debate. New York: Bloomsbury Academic.

Obama, B., 2014. "Remarks by President Obama at NATO Summit Press Conference". Available at http://www.whitehouse.gov/the-pressoffice/2014/09/05/remarks-president-obama-nato-summit-pressconference (accessed 5 October 2014).

Rubenzer, T., 2011. Campaign Contributions and US Foreign Policy Outcomes: An Analysis of Cuban-American Interests. American Journal of Political Science, 55(1): 105-116.

S. 2277, 1 May 2014. Available at https://www.congress.gov/bill/113thcongress/senate-bill/2277. (accessed 8 January 2015.) 
Shelbyville Daily Union, 2014. "Shimkus addresses current issues". 28 March 2014. Available at http://www.shelbyvilledailyunion.com/news/ shimkus-addresses-current-issues/article_bdf7ad52-ff 1 e-5fb8-90d9beeb5b44cae9.html (accessed 5 January 2015).

Shimkus, J., 2014. "Our Role in Europe". St. Louis Post-Dispatch, 6 March 2014: A15.

Shimkus, J., 2014a. Presentation at Eastern Illinois University. 6 October 2014.

Sloan, S. R., 2003. NATO, the European Union, and the Atlantic Community. Lanham MD: Rowman and Littlefield.

Souva, M. and Rohde, D., 2007. Elite Differences and Partisanship in Congressional Foreign Policy, 1975-1996. Political Research Quarterly, 60(1): 113-123.

United Macedonia Disapora, 2012. "Congressman Turner to Strengthen NATO Enlargement Bill". United Macedonia Diaspora, 23 February 2012. Available at http://www.umdiaspora.org/index.php/en/ frontpage-news/82-umdiaspora-latest-activity/130-congressmanturner-to-strengthen-nato-enlargement-bill (accessed 13 January 2015).

Wales Summit Declaration, 2014. Available at http://www.nato.int/cps/ en/natohq/official_texts_112964.htm, paragraph 92 (accessed 9 December 2014).

Weissman, S. R., 1995. A Culture of Deference: Congress's Failure of Leadership in Foreign Policy. New York: Basic Books.

Ryan C. Hendrickson is professor of political science and interim dean of the Graduate School at Eastern Illinois University. He is the author of three books, including most recently The Obama Wars: Congress and the Imperial Presidency (University Press of Kentucky, 2015). 